\title{
Familial visceral myopathy
}

INSERM

\section{Source}

INSERM. (1999). Orphanet: an online rare disease and orphan drug data base. Familial visceral myopathy. ORPHA:2604

Familial visceral myopathy is a rare hereditary myopathic degeneration of both gastrointestinal and urinary tracts that causes chronic intestinal pseudo-obstruction. It usually presents after the first decade of life with megaduodenum, megacystis and symptoms such as abdominal distension and/or pain, vomiting, constipation, diarrhea, dysphagia, and/or urinary tract infections.n. 